\title{
Neke novije komunikacijske teorije i njihova primjena na homiletiku
}

\author{
ENOH ŠEBA* \\ • https://doi.org/10.31823/d.28.1.6 • \\ UDK: $27-475^{*} 316.77$ • Pregledni članak \\ Primljeno: 5. srpnja 2019. • Prihvaćeno: 11. veljače 2020.
}

* dr. sc. Enoh Šeba, Sveučilište u Zagrebu, Sveučilišni centar za protestantsku teologiju

Matija Vlačić Ilirik, Ivana Lučića 1a, 10000 Zagreb, Hrvatska, enoh.seba@tfmvi.hr

Sažetak: Promatrano iz perspektive komunikacijskih procesa, opaža se da se tradicionalno propovijedanje uglavnom naslanja na linearan model interpersonalne komunikacije. Takva veza za sobom povlači i posljedice u vidu ograničenja koja otežavaju da propovijedanje ostvari puni komunikacijski potencijal. Stoga se razmatranjem novijih komunikacijskih modela (interakcijski i transakcijski) pokušava najprije rasvijetliti neke njihove specifične prednosti u odnosu na linearni model, a potom i uputiti na konkretne načine primjene u propovjednoj praksi koji će omogućiti njezino sveobuhvatnije razumijevanje i poboljšanje. Nadalje je namjera i naznačiti kako primjena tih spoznaja može redefinirati uloge ključnih aktera u homiletičkoj komunikaciji - propovjednika, vjernika i poruke. Temeljitost tih promjena upućuje na mogućnost da se propovijedanje počne sagledavati u okvirima jedne drukčije paradigme - konverzacije. Takva promjena očišta olakšava promišljanje propovijedanja koje, čuvajući svoj monološki oblik, ipak promiče dijalog, uzajamnost $i$ viši stupanj razumijevanja unutar vjerničke zajednice.

Ključne riječi: komunikacijske teorije, homiletika, propovijedanje, konverzacija, dijalog.

\section{Uvod}

Američki profesor homiletike James W. Cox jednom je napisao: »Propovijedanje mora biti jednako drevno poput istine koju naviješta i jednako suvremeno poput trenutka u kojem se ono događa. ${ }^{1} \mathrm{U}$ tom sljubljivanju drevnosti

${ }^{1}$ J. W. COX, Preaching, San Francisco, 1985., 29. 
naviještene istine i suvremenosti njezina izraza krije se izazov komunikacije, potencijal da ono izgovoreno i priopćeno bude shvaćeno i primljeno. Naime, bez obzira na to je li riječ o propovijedanju čija je nakana kerigmatski upoznati slušatelje s evanđeljem, o katehetskom instruiranju onih koji su evanđelje tek primili ili o homilijskom formiranju vjernika (kako to sažimlje Vladimir Zagorac), ${ }^{2}$ ono je uvijek obilježeno napetošću između mogućega uspjeha i neuspjeha. Upravo tu tenziju daje za naslutiti i novozavjetni poziv na komunikaciju Radosne vijesti: $\gg$ A kako da povjeruju u onoga koga nisu čuli? Kako pak da čuju bez propovjednika? « (Rim $10,14)$. Povrh toga, dva tisućljeća propovjedničke prakse i teoloških promišljanja potvrđuju svjedočanstvo Svetoga pisma da se u propovijedi neminovno nazire dvostruki subjekt - premda je primarni subjekt sam Bog, sekundarni subjekt propovijedanja uvijek je osoba propovjednika. ${ }^{3}$ Ako je dakle čin priopćavanja Božje samoobjave i oslovljavanja čovjeka neminovno zaodjeven u posredničke riječi izrečene ustima propovjednika (iako to priopćavanje može nadilaziti samo verbalnu razinu), onda nema ničega neprimjerenoga $\mathrm{u}$ tome da propovijedanje sagledavamo i kao specifičan oblik ljudske interpersonalne komunikacije koju lakše razumijevamo ako se poslužimo spoznajama različitih modela i teorija komunikacije.

Polazeći od tih pretpostavki, namjera ovoga članka jest najprije kratko promotriti propovijedanje iz perspektive komunikologije i upozoriti na implikacije koje donosi pristajanje uz određene (ponajprije linearne) modele komunikacije. Potom ću sažeto uputiti na uvide proizišle iz razvoja nekih novijih modela komunikacije i pojasniti kako oni transformiraju dotad dominantno poimanje interpersonalne komunikacije. Uslijedit će razmišljanje o implikacijama do kojih bi primjena tih uvida mogla dovesti na planu propovijedanja, a napose kako bismo mogli sveobuhvatnije gledati na uloge propovjednika, poruke i slušatelja. Na temelju toga i u dijalogu s novijom homiletičkom literaturom ${ }^{4}$ pokušat ću predstaviti konverzaciju kao moguću novu paradigmu propovijedanja.

\section{Propovijedanje i linearni model komunikacije}

Istraživanje područja komunikacije i teorija komunikacije otpočelo je tridesetih i četrdesetih godina 20. stoljeća, ponajprije u Sjedinjenim Američkim Državama.

\footnotetext{
${ }^{2}$ V. ZAGORAC, Homiletika, Zagreb, 2008., 7-11.

${ }^{3}$ Usp. isto, 19-32.

${ }^{4}$ Ovdje je većinom riječ o autorima koji dolaze s engleskoga govornoga područja i iz protestantskih crkvenih zajednica, a njihovi doprinosi potječu iz druge polovice prošloga stoljeća. Relativnu zapostavljenost misli o propovijedanju unutar katoličke teologije u cijelom postreformacijskom razdoblju, pa tako i u 20. stoljeću, Zagorac objašnjava ovako: »Budući da protestanti nisu napadali vrijednost propovijedanja, nego su je dapače visoko uzdigli, katolička je teološka misao na tom području zakržljala. « Isto, 30 .
} 
Novonastala disciplina u svojim začetcima oslanjala se na ranije poznate discipline, a svoj puni procvat doživjela je nakon Drugoga svjetskoga rata. Modeli koji nastaju u tom razdoblju i kojima se opisuje ljudska komunikacija uglavnom su linearni modeli. Svaki linearni model temeljno sačinjavaju tri elementa: pošiljatelj (osoba koja šalje poruku), poruka (informacija koju pošiljatelj šalje primatelju) i primatelj (osoba koja prima poruku). Proces komunikacije pokreće se u trenutku kada pošiljatelj oblikuje poruku pa je uputi prema primatelju, čija je uloga da tu poruku i primi. Da bi komunikacija uspjela, podrazumijeva se da postoji korespondencija između podražaja koji komunikator šalje i podražaja koji primatelj prima. Takav osnovni model potom se nadograđuje konceptima kao što su kodiranje (proces pretvaranja poruke u kodove koji se mogu poslati komunikacijskim kanalom i koje primatelj može razumjeti), kanal (medij putem kojega se poruka šalje), šum (smetnje koje tijekom procesa nastaju u kanalu) i dekodiranje (proces pretvorbe kodirane poruke u jezik koji primatelj razumije). Dobar primjer takvoga modela jest tzv. transmisijski ili Shannon - Weaver model koji su 1948. godine osmislili Claude Shannon i Warren Weaver, primarno za potrebe razumijevanja i razvoja komunikacijske tehnologije (telefona), a kasnije je korišten i u istraživanju i razvoju masovne komunikacije. ${ }^{5}$ Iste godine nastaje i Lasswellov model komunikacije. ${ }^{6}$ Odgovori na pitanja Tko je rekao?, Što je rečeno?, Kojim kanalom je to izrečeno?, Kome je rečeno? i Kakav je učinak rečenoga? otkrivaju pet glavnih sastavnica komunikacije: komunikatora, poruku, medij, slušateljstvo i učinke. Primjena toga modela bila je primarno fokusirana na propagandu s pomoću medija (TV i radio), ali je $s$ vremenom korištena i za interpersonalnu komunikaciju i širenje informacija među različitim skupinama u društvu.

Dakako, različite inačice toga modela podložne su sličnim kritikama i zahtijevaju konkretno naglašavanje svojih ograničenja. Ponajprije, jednosmjernost komunikacije čini takve modele neadekvatnima za cjelovito razumijevanje ljudske komunikacije. Temeljna pretpostavka u pozadini svakoga od tih modela jest aktivna uloga pošiljatelja, kao i pasivna uloga primatelja. Stoga se i istraživanja toga vremena najviše bave razradom znanstveno utemeljenih načina predviđanja kako će primatelji reagirati suočeni s određenom porukom. Drugim riječima, dok je u središtu interesa izučavanje uloge govornika i poruke, $\gg($...) slušatelji mogu biti predmetom proučavanja, ali samo kao meta. Analize slušatelja govorniku služe da bolje nacilja metu kako bi mogao pogoditi u središte i uvjeriti svoje slušatelje «?

${ }^{5}$ C. E. SHANNON, A mathematical theory of communication, u: Bell System Technical Journal 27(1948.)3, 379-423.

${ }^{6} \mathrm{H}$. D. LASSWELL, The structure and function of communication in society, $\mathrm{u}$ : The communication of ideas 37(1948.), 215-228.

${ }^{7}$ H. J. C. PIETERSE, Communicative Preaching, Pretoria, 1987., 25. 
Nadalje, linearni model ne uzima u obzir mogućnost da se istovremeno šalje više od jedne poruke, a istodobno podrazumijeva da svaki komunikacijski čin ima jasno definiran početak i završetak. Takav pogled na komunikaciju prilično je statičan, a ujedno i pretpostavlja poimanje stvarnosti kao potpuno spoznatljive realnosti i koristi se pretežno analitičkim, empirijskim i kvantitativnim podatcima. ${ }^{8}$ Posebno je delikatan problem feedbacka. Naime gotovo univerzalno isključivanje povratne komunikacije onemogućava bilo kakvu realnu provjeru učinka i ostavlja pitanje djelotvornosti komunikacije trajno otvorenim. Ključna metafora takvoga shvaćanja komunikacije jest isporuka ili prijenos, pri čemu se prenesena poruka primarno promatra kroz prizmu informacije ili sadržaja. ${ }^{9}$

Povijest kršćanskoga propovijedanja, iako iznimno slojevita i obilježena raznovrsnim mijenama potaknutim sociokulturnim, povijesnim i ekonomskim čimbenici$\mathrm{ma}^{10}$, otkriva da se ono u svojem razvoju relativno rano počelo određivati u odnosu prema Aristotelovu modelu komunikacije koji se pretežno zasnivao na njegovoj primjeni retorike. Iako je taj intenzivan odnos retorike i propovijedanja nemoguće jednoznačno ocrtati, reperkusije toga zagrljaja i dan danas lebde nad brojnim propovjedaonicama i ambonima različitih crkava. Upravo zato ovdje valja naznačiti nekoliko ključnih sastavnica Aristotelova modela. ${ }^{11}$

Govornikova funkcija jest slušateljstvu održati govor koji će oblikovati ovisno o prigodi (situaciji) i iznijeti ga s namjerom da na slušatelje utječe tako da postigne određeni učinak. U središtu zanimanja nalaze se govornik i poruka. U svojoj izvedbi i konstrukciji argumenta retor se služi kategorijama etosa, patosa i logosa. Da bi poruka polučila učinak kod slušateljstva, ona mora biti uvjerljiva. Stoga se govornik nastoji prikazati vjerodostojnim i stvaranjem percepcije kredibiliteta svoje osobe potaknuti slušatelje na prihvaćanje preferiranoga gledišta i/ili odlučivanja za određeni postupak (etos). Kad nastoji pobuditi suosjećanje, pozivat će se na osjećaje i emocije s kojima će se slušatelji lako identificirati te ih time navesti na spremnost da usvoje željene stavove (patos). Konačno, korištenjem razložno prezentiranim činjenicama i apeliranjem na njihov intelekt, retor također može postići da njegov argument bude doživljen kao logičan i naposljetku kao uvjerljiv (logos). Taj model

\footnotetext{
${ }^{8}$ S. W. LITTLEJOHN, Theories of Human Communication, Belmont, 1983., 302.

${ }^{9}$ Za podrobniji pregled toga modela usp. npr. S. L. TUBBS, Human Communication: Principles and Contexts, London, New York, 2013.

${ }^{10}$ Nije teško pronaći monografije koje kronološki iscrpno prikazuju kako je praksa propovijedanja razvijala svoje komunikacijske naglaske, ali vrijedi izdvojiti neke od njih. Npr. H. O. OLD, The Reading and Preaching of the Scriptures in the Worship of the Christian Church, VII, Grand Rapids, 1998-2010.; O. C. EDWARDS, A History of Preaching, Nashville, 2010.
}

${ }^{11}$ ARISTOTEL, Retorika, Zagreb, 1989. 
Aristotel je razvio u demokratskom okruženju antičke Grčke, gdje su skupovi građana donosili odluke o političkim poslovima polisa ili razmatrali slučajeve iznesene pred sudove. U svakom slučaju, riječ je o obliku javnoga govora držanom pred relativno homogenom grupom slušatelja koja je trebala donijeti određeni sud.

Očigledne su sličnosti Aristotelova modela s linearnim modelom koji sam ranije opisao. I ovdje se komunikacija odvija isključivo jednosmjerno - od govornika prema slušateljstvu. Aktivan je samo govornik, to jest jedina aktivna uloga slušatelja moguća je u obliku reakcije na poruku priopćenu radi utjecanja na slušatelje. Povratna informacija ili dvosmjernost komunikacije nije predviđena u tom modelu, a ne postoji ni svijest o utjecaju šuma ili distrakcija koje mogu otežati ili onemogućiti komunikacijski proces.

Kristijanizacija klasične retorike koju je krajem 4. i početkom 5. stoljeća proveo Augustin uključivala je i internalizaciju Aristotelova komunikacijskoga modela koji se pokazao pogodnim u novonastalim društvenim okolnostima nakon što kršćanstvo postaje priznata religija, a propovijed se sve više pretvara u javan diskurs pred sve brojnijim slušateljstvom koje treba formalnim oblicima persuazije upoznati $s$ istinama evanđelja. Među stručnjacima tako postoji gotovo pa neupitan konsenzus da su Augustinovo prisvajanje i prilagodba klasične retorike više od tisuću godina slovili kao neupitan autoritet na području homiletike. Moglo bi se reći da se tijekom svih tih stoljeća homiletička retorika postojano razvijala na Augustinovu nasljeđu, a time i perpetuirala aristotelovski model komunikacije.

Okrenemo li se sadašnjemu vremenu, vjerujem da čak i površnom poznavatelju propovjedničke prakse nije teško opaziti da se u mnogim (većini?) crkvama komunikacija tijekom propovijedi i dalje odvija prema sličnim obrascima. Istina, ne dijele sve crkvene tradicije isti stav i vjerovanja po pitanju uloge i značaja propovijedi, a na razini njezine izvedbe sasvim sigurno postoje brojne različitosti i nijanse, čak i unutar iste tradicije. Drugim riječima, postoje propovjednici čiji nastup i stil odudara od ustaljenih homiletičkih uzusa. Pa ipak, širi presjek otkriva da se pri propovijedanju komunikacijski proces ostvaruje uglavnom na način koji preslikava i odražava ključne odrednice linearnoga modela.

Tako je, recimo, jasno da je propovjednik taj koji oblikuje poruku za cijelu zajednicu. Propovijed ne postoji dok je propovjednik ne pripremi - ona počinje s propovjednikom, a u određenom smislu gotova je čak i prije nego bude izgovorena, dakle prije susreta s vjernicima. Nadalje je propovijed gotovo bez izuzetka monološki tip komunikacije. Iako u činu propovijedi imamo dvije strane - propovjednika i njemu okrenutu zajednicu - čuje se glas samo jedne strane (u zajednicama gdje se koristi razglas taj je odnos još istaknutiji činjenicom da je mikrofon postavljen samo pred propovjednika). Dakle evidentna je stroga razdioba između propovjednika kao ak- 
tivnoga pošiljatelja i vjernika kao pasivnih primatelja, a crta razgraničenja oštra je i ne dopušta (privremenu) zamjenu uloga. U skladu s tim propovijedanje se temelji na očekivanju da će propovjednikova uvjerljivost propovijedanja dovesti do toga da propovijed postane normativna za svakoga slušatelja. Rečeno drukčije, homiletička komunikacija jest uspješna ako vjernici prihvate propovjednikovu poruku - a to znači da je postignut određeni učinak: da je došlo do produbljivanja njihova znanja o Bogu, do usvajanja novih uvjerenja i vjerovanja ili do donošenja važnih životnih odluka. Presudna svrha propovijedanja prema tomu jest prenijeti poruku.

Međutim u drugoj polovici 20. stoljeća sve je izraženija svijest o manjkavostima takvoga modela komunikacije u propovijedanju. Naime jednosmjerna komunikacija zapravo ne posjeduje ugrađene mehanizme uz pomoć kojih bi se mogla vrjednovati stvarna učinkovitost bilo pojedinačne propovijedi bilo kontinuiteta službe propovijedanja. Shodno tomu, i među propovjednicima i među homiletičarima jača empirijski dojam da je sve manje i manje dokaza za zbiljske, značajne promjene u životima pojedinaca i zajednica, promjene koje bi se moglo smatrati konkretnim rezultatima i učincima propovijedanja. ${ }^{12}$ Neki autori drže da je upravo linearna komunikacija odgovorna za taj podbačaj. Tako David Brown pojašnjava da linearni model promiče $\gg$ mit prisjećanja $\ll$. Jednosmjernost propovijedi naime zahtijeva da se sadržaj pohranjuje u memoriju kako bi se slušatelji kasnije mogli prisjetiti poruke propovijedi. ${ }^{13}$ Ta sposobnost prisjećanja trebala je zajamčiti da će se u životu slušatelja naknadno dogoditi promjena.

Time se naznačuje barem jednako važan problem linearnoga komuniciranja u propovijedanju. Naime time se slušatelji propovijedi postupno degradiraju u puke konzumente religijskoga sadržaja i teološke pouke - sve što oni mogu učiniti u svezi s homiletičkom komunikacijom koju odslušaju nedjeljom u crkvi jest to da im se ona svidi ili ne svidi. Izrečeno malo drukčije, vjernička zajednica ostaje samo pasivan promatrač vjerskoga performansa u izvedbi klera. ${ }^{14}$ Nadalje takav pristup ne uzima u obzir činjenicu da vjernici (zapravo svaki slušatelj/ica propovijedi) pri

\footnotetext{
${ }^{12}$ Ovdje valja napomenuti kako je ta pojava snažnije istaknuta u onim crkvenim zajednicama, ponajprije protestantskim, koje u središtu svojega liturgijskoga života imaju službu riječi. Otuda slijedi i izraženije očekivanje da će upravo propovijedanje biti ishodište i žarište promjena u životima vjernika i njihovim uvjerenjima.

${ }^{13}$ D. M. BROWN, Transformational Preaching: Theory and Practice, College Station, 2003., 183.

${ }^{14} \mathrm{Na}$ tom tragu homiletičar Wesley $\mathrm{O}$. Allen iznio je zanimljiv povijesni komentar. On kaže kako je nakon reformacije došlo do toga da se bogoslužje $\gg . .$. iz promatračke liturgije (u smislu da zajednica promatra kako se sakramenti podjeljuju na latinskom) « pretvorilo $\gg . . . u$ liturgiju slušanja (u smislu da zajednica sluša kako im se Riječ naviješta na njihovom materinjem jeziku) «, ali da je osnovni obrazac pasivnoga sudjelovanja ostao netaknut. Usp. W. O. ALLEN, The Homiletic of all believers: a conversational approach, Louisville, 2005., 43.
} 
slušanju propovijedi već imaju određeno predrazumijevanje biblijskoga teksta ili teme. U tom smislu propovijed kao prenošenje činjenica i dobro definiranih odgovora može promašiti svoj cilj kada nudi rješenja za nepostojeće probleme ili odgovore na pitanja koja slušatelji zapravo ne postavljaju. U sličnom smjeru ide i jedan od radikalnijih kritičara tradicionalnoga propovijedanja Doug Pagitt kada kaže da je potrebno osporiti ideju da gomilanje nečijega znanja o Bogu predstavlja najdjelotvorniji način produbljivanja duhovnoga života. ${ }^{15}$ Takve i slične kritike upozoravaju na zasnovanost propovijedanja na pretpostavci da će činjenično znanje, prikupljeno uglavnom pasivnim procesom slušanja, nekako dovesti do aktivne promjene ponašanja.

\section{Neka novija otkrića na području komunikacijskih teorija}

Već sam ranije naznačio da je jedan od glavnih nedostataka linearnoga modela njegova nemogućnost da sagleda cirkularnu i simultanu prirodu procesa komunikacije. Primatelj će gotovo neizbježno, gotovo uvijek nakon (ili čak tijekom) primanja izvorne poruke preuzeti ulogu pošiljatelja te oblikovati svoj odgovor. Iz toga razloga komunikolozi smatraju da Søren Kierkegaard, koji je primatelja postavio na središnje mjesto komunikacijskoga procesa, dodijelio mu jednaku vrijednost kao i pošiljatelju te inzistirao da se proces mora proučavati u cijelosti, zaslužuje biti prozvan ocem moderne komunikacije. ${ }^{16}$ Teorijski radovi Karla Jaspersa zajedno s interesom za publicistiku, političke znanosti i marketinšku industriju nakon Drugoga svjetskoga rata ${ }^{17}$ imali su ključan utjecaj na razvoj teorija komunikacije koje se od tada počinju množiti. Iako je danas posve jasno da ne postoji konsenzus oko jedne teorije komunikacije koja bi bila prihvatljiva i jednako relevantna za raznorodna područja i vrste komunikacijskih procesa, tijekom druge polovice prošloga stoljeća razvijaju se, među ostalim, dva novija modela koja postupno zadobivaju sve konkretniju potvrdu kao valjani načini objašnjenja interpersonalne komunikacije - riječ je o interakcijskom i transakcijskom modelu. ${ }^{18}$ Evo nekoliko elementarnih

${ }^{15}$ D. PAGITT, Reimagining Spiritual Formation: A Week in the Life of an Experimental Church, El Cajon, Grand Rapids, 2004., 22. Na drugom mjestu on propovijed označava terminom »speeching «, što bi u slobodnom prijevodu moglo značiti »govorancija « i smatra je tek govorom koji ima religijski sadržaj. Usp. D. PAGITT, Preaching Re-Imagined: The Role of the Sermon in Communities of Faith, Grand Rapids, 2005.

${ }^{16}$ H. J. C. PIETERSE, Communicative Preaching, 25-26.

${ }^{17}$ Isto, 26-27.

${ }^{18}$ Nešto detaljniji uvodni pregled bitnih značajki tih modela i korisnu bibliografiju za daljnje istraživanje čitatelj može pronaći u: S. L. TUBBS, Human Communication: Principles and Contexts, 4-13. Vrlo korisno za temeljitije izučavanje jest u: K. MILLER, Communication Theories: Perspectives, Processes, and Contexts, New York, 2004. 
zapažanja koja će nam dati uvid u njihove razlikovne karakteristike u odnosu na linearan model.

Temelje interakcijskoga modela komunikacije postavio je 1967. godine psiholog, obiteljski psihoterapeut i teoretičar Paul Watzlawick. ${ }^{19}$ Na primjeru obitelji on je proučavao kako funkcionira komunikacija unutar sustava te dokazivao da je komunikacija neizostavna za uspostavu odnosa s drugima. Budući da je vlastita samopercepcija neminovno određena odnosom s drugim ljudima, on upravo odnose smješta na samo polazište svoje teorije komunikacije. Cijelu teoriju možemo ukratko (premda paušalno) promotriti kroz njegovih pet aksioma komunikacije bez kojih je nemoguće zadržati ravnotežu unutar sustava i čije uvažavanje osigurava djelotvoran komunikacijski proces.

1. Nemoguće je ne komunicirati. Baš svako ponašanje predstavlja određeni oblik komunikacije, pa tako i šutnja ili odbijanje stupanja u komunikaciju znači određeni komunikacijski čin.

2. Svaka komunikacija posjeduje sadržajnu i odnosnu dimenziju pri čemu potonja određuje onu prethodnu. Da bi primatelj do kraju razumio poruku, on/ona treba moći protumačiti ne samo informacije koje je priopćavatelj prenio nego i informacije o tome kako osoba koja šalje informacije želi biti shvaćena i u kakvom se odnosu nalazi prema primatelju. Odnosni dio komunikacije otkriva i da feedback primatelja uvjetuje ponašanje priopćavatelja, a to potom dovodi do toga da je ponašanje svakoga pojedinca neizostavno uvjetovano ponašanjem ostalih sudionika u komunikaciji.

3. Priroda odnosa ovisi o interpretaciji tijeka komunikacije. I pošiljatelj i primatelj doživljavaju svoje ponašanje kao reakciju na ponašanje one druge strane, ali se ne moraju slagati u tumačenju što je uzrok, a što posljedica u nizu postupaka.

4. Komunikacija se uvijek odvija na dvjema razinama - verbalnoj i neverbalnoj. Njih dvije nije moguće raščlaniti, iako pošiljatelj potonju često oblikuje manje svjesno nego što je slučaj s verbalnim dijelom. Verbalna razina služi za prijenos sadržajne dimenzije poruke, dok neverbalna djeluje tako da priopćava važne informacije o odnosnoj dimenziji.

5. Komunikacijski procesi mogu biti simetrični ili komplementarni. U simetričnim razmjenama interakcija je zasnovana na ravnopravnim odnosima moći. $U$ komplementarnim razmjenama interakciju definiraju nerazmjeri moći među sudionicima. Zdrava komunikacija uključuje, ovisno o situaciji i naravi sudionika, kombinaciju obiju vrsta procesa.

${ }^{19}$ P. WATZLAWICK, J. B. BAVELAS, D. D. JACKSON, Pragmatics of Human Communication: A Study of Interactional Patterns, Pathologies and Paradoxes, New York - London, 2011. 
Transakcijski komunikacijski model (poznat i kao cirkularni model) uglavnom potječe iz složenoga modela koji je 1970 . godine predstavio D. C. Barnlund. ${ }^{20}$ Riječ je o višeslojnom sustavu povratnih informacija u kojem recipročno povezani priopćavatelj i primatelj naizmjence mijenjaju svoje uloge, a obje strane šalju feedback tako da povratna informacija jedne strane predstavlja poruku za onu drugu stranu. Uspjeh komunikacije uvelike ovisi o sustavu aluzija kao znakova koji sačinjavaju područje iskustva koje pošiljatelj i primatelj dijele. Posebna vrijednost toga modela jest to što se njime rasvjetljava ne samo međuovisnost primatelja i pošiljatelja nego i ovisnost procesa komunikacije o ukupnosti činjenica o nekoj osobi ili grupi unutar društvenih, kulturnih i odnosnih konteksta. Primjera radi, vrijednosti, norme, zakoni (društveni kontekst), rasa, nacionalna pripadnost, društvena klasa (kulturni kontekst), povijest međusobnih odnosa (odnosni kontekst) - sve su to čimbenici koji mogu poboljšavati ili obeshrabrivati komunikaciju. Unutar tih konteksta odvijaju se procesi kodiranja, dekodiranja i interpretacije, što samo znači da je pitanje okolnoga šuma i komunikacijskih barijera znatno složenije i delikatnije nego što su to implicirali raniji modeli. Konkretno, izvori šuma mogu se podijeliti na fizičke (npr. glasni zvučnici, glasan razgovor u drugoj prostoriji), fiziološke (npr. prebrzo i nerazgovijetno govorenje) i psihološke (npr. odsutnost misli, predrasude). Tako složen proces komunikacije na koncu dovodi do toga da značenje nikako nije nešto što se prima, nego nešto što nastaje tijekom kompleksnoga, ireverzibilnoga, dvosmjernoga i dinamičnoga procesa u kojem pošiljatelj i primatelj imaju jednakovrijednu važnost.

Iz dosad rečenoga proizlazi da možemo istaknuti neke zajedničke nazivnike takvih modela.

1. Prije svega, oni obuhvaćaju ranije zanemarivane elemente komunikacijskoga procesa i time pokazuju da je priroda odnosa između sudionika komunikacije daleko složenija i utjecajnija nego što je to implicirano tradicionalnim modelom.

2. Nadalje, pošiljatelj ne može nepovratno definirati značenje poruke prije njezina prijenosa - naprotiv, poruka najčešće poprima svoje (privremeno) značenje tek na primateljevoj strani komunikacijskoga procesa. Iz toga slijedi da time primatelj ima ulogu sukreatora značenja poruke.

3. Dok je linearni model komunikaciju promatrao primarno kroz prizmu verbalnoga izražavanja, ti modeli nedvojbeno zadiru ispod te razine i upozoravaju na iznimnu važnost neverbalnih elemenata. Štoviše, brojne studije pokazuju da u interpersonalnoj komunikaciji $\gg \ldots$ verbalne komponente prenose manje od

${ }^{20}$ D. C. BARNLUND, A transactional model of communication, u: C. D. MORTENSEN (ur.), Communication Theory, New York - London, 2017., 47-57. 
$35 \%$ društvenog značenja situacije, a više od $65 \%$ prenosi se neverbalnim putem $^{21} \ll$. Pri tome su, podsjeća nas Myron R. Chartier, neverbalne informacije dominantne jer se svakodnevno opažaju i prikupljaju ne samo osjetilima već i podsviješću i intuicijom. ${ }^{22}$ Budući da je svaka poruka satkana ne samo od riječi nego i od širokoga raspona vokalnih, facijalnih, tjelesnih i drugih signala, postoji nerazdruživa povezanost svjesnih i nesvjesnih signala.

\section{Primjena na homiletiku}

Na samom početku ovoga članka istaknuo sam činjenicu da propovijedanje svakako možemo promatrati kao oblik ljudske komunikacije. Sada je prikladan trenutak da podsjetim i na njegovu metafizičku dimenziju - naime propovijedanje samo po sebi opravdanje pronalazi u onoj mjeri u kojoj je potaknuto fundamentalnijom komunikacijom i u onoj mjeri u kojoj je na tu istu komunikaciju upućeno - riječ je, dakako, o božanskoj samoobjavi. Naime valja se na čas prisjetiti da je i sama kršćanska Crkva začeta tek nakon što je Bog odlučio postati čovjekom i time pokrenuo onaj krajnji komunikacijski čin - čin priopćavanja sebe samoga. Kraft je tu samoobjavu sažeto opisao ovim riječima: »Utjelovljenje je Božja osnovna metoda [komunikacije]. ${ }^{23} S$ obzirom na to da je Božja voljnost da se do kraja razotkrije (priopći) čovjeku svoj vrhunski izraz pronašla u Kristovu utjelovljenju, praktički je nemoguće otkloniti zaključak da je inkarnacija teološka osnova komunikacije koja se događa kad god netko s propovjedaonice otvori Riječ Božju i pokuša navijestiti stvarnost Boga koji je došao i koji će doći ponovno. U isto vrijeme svaka je propovijed neminovno i odjek gromoglasnoga navještaja utjelovljenja, omeđenoga događajima rođenja, života, patnje, smrti i uskrsnuća Isusa Krista, Sina Božjega.

Ako je dakle sprega kršćanskoga propovijedanja i komunikacije među ljudskim bićima tako iskonska, nije li mudro razmisliti o tome kako nam novije spoznaje o naravi ljudske komunikacije mogu pomoći ujedno bolje razumjeti, ali i unaprijediti praksu propovijedanja? Stoga ću u nastavku ponuditi nekoliko mogućih smjerova razmišljanja potaknutih specifičnim implikacijama koje izviru iz dosad predstavljenih informacija. Pritom ću se, iako suvremeni teoretičari komunikacija najčešće upotrebljavaju pet komponenti komunikacije (pošiljatelj, primatelj, poruka, medij i povratne informacije - feedback), ipak zadržati na promišljanju potencijalnih pro-

\footnotetext{
${ }^{21}$ M. L. KNAPP, Nonverbal Communication in Human Interaction, New York, 1972., 12.

${ }^{22}$ M. R. CHARTIER, Preaching as Communication: An Interpersonal Perspective, Nashville, 1981., 84. Ovdje nije naodmet dodati i da su neverbalna komunikacijska sredstva znatno uspješnija u prenošenju emocija te da upravo ona igraju presudnu ulogu u definiranju odnosa (isto, 89-90.).

${ }^{23}$ C. H. KRAFT, Communication Theory for Christian Witness, New York, 1991., 25.
} 
mjena u području prvih triju komponenti. ${ }^{24}$ Razlozi za to jesu dvojaki. Kao prvo, postojeća homiletička literatura proces komunikacije i dalje najvećim dijelom razmatra unutar trokuta propovjednik - poruka - slušatelji. Kao drugo, širenje rasprave na preostale elemente zacijelo bi zahtijevalo opsežniju obradu. Stoga ću se ograničiti na to da ocrtam ona mjesta u homiletičkoj teoriji (pa i praksi) koja valja podvrgnuti preispitivanju u svjetlu uvida koje donose teorije komunikacije. Naposljetku upućeniji izučavatelj suvremene homiletike, a napose one nastale u protestantskom okruženju na zapadu, primijetit će da se ovaj članak dotiče tek jednoga od okidača promjena koje su zahvatile propovijedanje u brojnim crkvenim tradicijama i pokrenule nove načine teološkoga promišljanja kršćanske zadaće propovijedanja. Dakako, i ovdje je riječ o preširokom području da bismo ga adekvatno obradili ovako sažetim tekstom. ${ }^{25}$

\subsection{UlOGA PROPOVJEDNIKA}

U propovijedanju koje slijedi linearni model komunikacije propovjednik posjeduje znatan autoritet koji se rijetko ili nikada ne preispituje niti dijeli. Naime propovjednika se percipira kao onoga tko kreira poruku i njezino značenje ili kao onoga tko posreduje između Riječi Božje i naroda. U oba slučaja propovjednik je taj koji prenosi dovršenu poruku, pa mu se zbog toga, premda i samo implicitno, pridaje poseban autoritet. Konačno, riječ je o posebnoj službi koju u trenutku propovijedanja može obavljati samo jedna osoba (a u većini slučajeva to je i crkveni službenik, svećenik, koji je zadužen i za druge pastoralne zadaće u zajednici). Uzdignut položaj propovjedaonice u crkvi najčešće zorno prikazuje upravo tu izdvojenost ili $d r u g o s t$ propovjednika u odnosu na ostatak zajednice. Taj jaz i nerazmjer autoriteta katkad se dodatno produbljuje u situacijama u kojima propovjednik svoju propovijed čita s papira jer time signalizira nevažnost odnosa sa slušateljima. ${ }^{26}$

${ }^{24}$ Tako Pieterse na primjer smatra da »osnovni sastojci modernog komunikacijskog modela i dalje ostaju sadržani u triptihu pošiljatelj, medij i primatelj, uzimajući pritom u obzir odnose među sudionicima i njihove okolnosti« (usp. H. J. C. PIETERSE, Communicative Preaching, 30.).

${ }^{25}$ Suvremena homiletička gibanja potaknuta su različitim disciplinama - osim teorija komunikacije, značajnu ulogu odigrali su i filozofija jezika (hermeneutika), teorija književnosti (primjerice teorija čitateljske reakcije i narativna kritika) i retorika. Informativne preglede tih utjecaja i korisnu bibliografiju čitatelji mogu pronaći u: R. J. ALLEN, The turn to the listener: a selective review of a recent trend in preaching, u: Encounter 64(2003.)2, 173-188.; E. R. RIEGERT, What is Authoritative for the $\gg$ Post-modern « Listener, u: Currents in Theology and Mission 25(1998.) 1, 5-14.; D. J. RANDOLPH, The Renewal of Preaching, Philadelphia, 1969.

${ }^{26}$ Mnogi homiletičari ističu važnost propovijedanja ex tempore kao preduvjet uspješne komunikacije. Vidi npr.: J. M. WEBB, Preaching Without Notes, Nashville, 2010. Čak je i John A. Broadus, u svojoj knjizi koja je sve do polovice prošloga stoljeća glasila za najznačajnije homiletičko djelo na engleskom govornom području nakon Augustinove De Doctrina Christiana, ustvrdio: »A što se 
Nasuprot tomu, spoznaje koje nam dolaze s pomoću novijih komunikacijskih teorija jasno signaliziraju kako bi značajniju ulogu trebalo pripisati recipročnosti tijekom komunikacijskoga čina. Čak i neke naoko sitnije promjene u tehnici propovijedanja mogu poboljšati uzajamnost - na primjer kontakt očima za vrijeme propovijedanja vrlo dobro reprezentira simultanu prirodu komunikacijskoga procesa, kao i važnost koju neverbalni segment ima za djelotvornu komunikaciju. Naime propovijedanje kao čin usmene komunikacije uključuje neposrednost, što znači fizičku nazočnost propovjednika i slušatelja cijelo vrijeme trajanja propovijedi. Iz toga slijedi da obje strane imaju svoj komunikacijski potencijal kojim se mogu koristiti istodobno, a koji ne mora biti (a u praksi nikad ni ne može biti) sveden na verbalni iskaz samo jedne od njih (propovjednika).

Takva recipročnost međutim može imati i dalekosežnije posljedice, ponajprije po shvaćanje raspodjele autoriteta. Ona odbija doživljavati propovjednika kao »( ... autoritet koji s visoka obznanjuje istinu «, već pretpostavlja da su ona ili on pripadnici zajednice čije se naviještanje odvija $\gg . .$. prezentiranjem dinamike konverzacija koje vode predstavnici zajednice $\ll .{ }^{27}$ To nikako ne znači da propovjednik nema nikakav autoritet, već da početni autoritet koji je primio s položajem propovjednika - svećenika tek treba nadograditi tako da postupno stekne povjerenje svojih slušatelja. Ta odnosna dimenzija komunikacije često može igrati presudnu ulogu u recepciji propovijedi. Još je Augustin upozoravao na snagu propovjednikovoga etosa koji može govoriti glasnije i uvjerljivije od njegovih riječi: »... za nas koji težimo tome da nas drugi čuju i poslušaju, više od ikakve grandioznosti stila važniji je život govornika. $\ll^{28}$ Rečeno drukčije, autoritet postaje pitanje vjerodostojnosti i autentičnoga življenja u svakodnevnici. Chartier sugerira da se takav autoritet može izgraditi jedino pomoću odnosa sa zajednicom koji je bitno obilježen »samoobjavom $\ll .{ }^{29}$ Umjesto da samo igra ulogu propovjednika ili se čak skriva iza nje, osoba za propovjedaonicom mora ogoliti svoju istinsku ljudskost, otkriti svoje pozitivne i negativne strane pred slušateljstvom jer i ona pripada toj zajednici kojoj propovijeda. Lucy Lind Hogan i Robert Reid čak navode specifične karakteristike kakve bi propovjednik trebao posjedovati: pozornost, inteligenciju, razboritost i

tiče same izvedbe, propovijed može biti savršeno prirodna i ostvariti najbolji učinak samo ako se na ovaj ili onaj način izgovara bez bilježaka (...) samo tako će glas, ponašanje i oko biti upravo ono što priroda nalaže i ostvariti svoju punu snagu.« Usp. J. A. BROADUS, On the Preparation and Delivery of Sermons, San Francisco, 1979., 271.

${ }^{27}$ O. W. ALLEN, The Homiletic of All Believers: A Conversational Approach to Proclamation and Preaching, Louisville, 2005., 10.

${ }^{28}$ R. P. H. GREEN, Saint Augustine: On Christian Teaching, Oxford, 1997., 4.151.

${ }^{29}$ On najprije sažeto prikazuje prepreke samoobjavi (M. R. CHARTIER, Preaching as Communication, 36-39.), a zatim nudi i neke smjernice za njezinu primjenu (isto, 39-43.). 
odgovornost. ${ }^{30}$ Craig Loscalzo savjetuje propovjednicima da štite i komuniciraju svoj moralni integritet, da budu otvoreni u pogledu moralnih dvojbi, kao i da budu autentični u priznavanju svojih ograničenja: »Prepoznavanjem svoje ljudskosti slušateljima dopuštate da i oni prepoznaju svoju. $\ll^{31}$

Taj naglasak na vjerodostojnosti propovjednika važan je iz još jednoga razloga. Naime dvosmjerna komunikacija traži da se i propovjednik prilagođava svojim slušateljima, da traži načine kako olakšati komunikaciju te da učini sve da poruka slušateljima bude čujna, razumljiva i otvorena za interpretaciju. Upravo u svjetlu te potrebe valja shvatiti potrebu za vjerodostojnošću propovjednika - njegovo poslanje nije samo sveto govoriti već je u najmanju ruku jednako važno i da sveto živi. Svoju poruku doista približava slušateljima samo onda kada oni imaju stvaran dojam da on tu poruku i utjelovljuje vlastitim životom!

Nije pretjerano ako kažemo da je autoritet propovjednika značajno preobražen u svjetlu novijih komunikacijskih teorija. Propovjednik je možda ranije mogao predstavljati dispečera i posrednika neupitnoga autoriteta koji sa sigurne distance odašilje vječne istine pasivnim slušateljima čiji je jedini izbor prihvatiti ili odbaciti poruku. Međutim danas je lako moguće da se njegov autoritet oblikuje dok nasljeduje Božji način komuniciranja, dakle onda kada priopćava poruku s pomoću vlastitoga utjelovljivanja izgovorene riječi. Ako je to točno, onda je uloga propovjednika možda dramatično izmijenjena, ali njegova odgovornost nije umanjena niti mu je autoritet izgubljen.

\subsection{UlOGA PORUKE}

I u sferi poruke nailazimo na važne implikacije otkrića komunikacijskih teorija. Već sama činjenica da je oblikovanje poruke nerazmrsivo vezano uz fino razgranatu mrežu odnosa između propovjednika i članova zajednice koji propovijed slušaju predstavlja izvorište bitnih spoznaja. Ovdje ću pokušati ukratko naznačiti njezine tri posljedice.

Kao prvo, kako sam maloprije pokušao pokazati, čini se neporecivim da propovjednikova osobnost i stavovi utječu i na postupak oblikovanja poruke. ${ }^{32} \mathrm{Iz}$ toga slijedi

\footnotetext{
${ }^{30}$ L. L. HOGAN, R. REID, Connecting with the Congregation: Rhetoric and the Art of Preaching, Nashville, 1999., 63-64.

${ }^{31}$ C. A. LOSCALZO, Preaching sermons that connect: effective communication through identification, Downers Grove, 1992., 72.

${ }^{32} \mathrm{U}$ svojem istraživanju, provedenom na uzorku od više od dvjesto bogoslužja, nizozemski pastor i psiholog Hans van der Geest bavio se kratkoročnim učinkom propovijedi na slušatelje i ustanovio je vrlo blisku povezanost s propovjednikovom osobnošću. Usp. H. van der GEEST, Presence in the Pulpit: The Impact of Personality in Preaching, Atlanta, 1981., 143-163.
} 
da nije rijetkost da vjernici propovijed interpretiraju kroz prizmu svojega odnosa s propovjednikom, kao ni da su skloni lakše se s njom povezati i spremnije prihvatiti njezinu poruku ako smatraju da propovjednik govori i iz vlastitoga, autentičnoga iskustva te ako u njegovoj perspektivi mogu nazrijeti da se on trudi razumjeti i njihovu životnu situaciju. Postojeća empirijska istraživanja o očekivanjima i dinamici slušanja propovijedi to prilično jasno potvrđuju. ${ }^{33}$

Kao drugo, poruka propovijedi nikako nije svediva na propovjednikovu verbalnu komunikaciju. Time se želi reći da poruku više ne možemo predvidivo ograničiti samo na njegove riječi, baš kao što nemamo prava zaključiti da se njome prenose isključivo informacije. Teorije komunikacije uče nas da je poruka satkana i od emocija, raspoloženja, doživljaja i iskustva. U prilog tomu ide Van der Geestov zaključak o tome kako slušatelje više zanima utjecaj onoga što je izrečeno od samoga sadržaja tih riječi. U skladu s tim je i tvrdnja da propovjednički navještaj ne obuhvaća samo sadržaj i jezik nego $\mathrm{i} \gg$ cjelokupnu propovjednikovu sposobnost komuniciranja ili ometanja komuniciranja «. ${ }^{34}$ Toj sposobnosti svakako pripada i korištenje neverbalnim sredstvima komunikacije kao što su ton i brzina govora, pogled, geste, mimika i kretanje u prostoru. Štoviše, propovjednik može u bilo kojem trenutku prekinuti svoju verbalnu komunikaciju, ali ona neverbalna sigurno će se nastaviti događati. Osim toga poruku više nije moguće promatrati izdvojeno jer, kako to tumači Pieterse, ona uvelike ovisi o prirodi i kvaliteti komunikacije, na koju pak utječe »priroda medija - tj. radi li se o jednosmjernom ili otvorenom mediju $\ll .{ }^{35}$ Premda je propovijed kroz povijest uglavnom egzistirala u svojem monološkom obliku koji je primarno jednosmjeran medij, ${ }^{36}$ čini se da sama narav interpersonalne komunikacije uvijek implicira postojanje barem minimuma recipročnosti. U tom pogledu moglo bi se reći kako bi bogatstvu i višeslojnosti komunikacije propovijedanja vje-

\footnotetext{
${ }^{33}$ Osim već spomenutoga istraživanja ovdje valja navesti i opsežno istraživanje pod nazivom Listening to Listeners, provedeno 1999. godine u SAD-u pod pokroviteljstvom fondacije Lily Endowment. Rezultati toga pionirskoga pothvata objavljeni su u četirima zasebnim svescima: R. J. ALLEN, Hearing the Sermon: Relationship, Content, Feeling, Channels of Listening, St. Louis, 2004.; M. A. MULLIGAN, D. TURNER-SHARAZZ, D. O. WILHELM, Believing in Preaching: What Listeners Hear in Sermons, Channels of Listening, St. Louis, 2005.; M. A. MULLIGAN, R. J. ALLEN, Make the Word Come Alive: Lessons from Laity, Channels of Listening, St. Louis, 2005.; J. S. McCLURE i dr., Listening to Listeners: Homiletical Case Studies, Channels of Listening, St. Louis, 2004.

${ }^{34}$ H. van der GEEST, Presence in the Pulpit: The Impact of Personality in Preaching, 153.

${ }^{35}$ H. J. C. PIETERSE, Communicative Preaching, 32.

${ }^{36} \mathrm{U}$ jednom od najranijih istraživanja propovijedi sa stajališta komunikacije Clyde $\mathrm{H}$. Reid zaključio je da propovijed predstavlja jedan oblik masovne komunikacije, pa je kao takva neprikladna za uvjeravanje slušatelja kad je riječ o izrazito kontroverznim pitanjima. Usp. C. H. REID, The Empty Pulpit: a Study in Preaching as Communication, New York, 1967.
} 
rojatno više odgovarao komunikacijski kanal koji bi u sebi dopuštao više prostora za uzajamnost i dijalog.

Kao treće, možda i najveći pomak nalazimo u području značenja. Riječi same po sebi ne posjeduju intrinzična značenja - slušatelj je taj koji riječima daje značenja. ${ }^{37}$ Shodno tomu, ne može se očekivati da će značenje biblijske poruke izrasti izravno iz svetopisamskoga teksta ili iz propovjednikova izlaganja, već tijekom procesa u kojem slušatelji internaliziraju poslanu poruku. Randolph je tu dinamiku sjajno pretočio u jedan od postulata homiletike koja se počela razvijati na sjevernoameričkom kontinentu u drugoj polovici 20. stoljeća: »Propovijed teži konkretizaciji, ali ne na apstraktan način tako da samo izloži tekst u odnosu na njegovu pozadinu, nego izricanjem njegova značenja u situaciji u kojoj se nalaze slušatelji. $\ll^{38}$ Time se oblikovanje poruke stavlja u znatno izraženu korelaciju prema slušateljima i njihovim kontekstima. $U$ isto vrijeme postaje vidljivo i da su granice nastajanja i dovršavanja poruke daleko fluidnije te da su one najvećim dijelom smještene u kontekst interakcije propovjednika i pastve.

\subsection{Uloga SLUŠATELJA}

Ostaje pozabaviti se nakratko i trećim elementom propovijedanja, a to su slušatelji. Njihova uloga više nije samo pasivna i nekritička recepcija poslane poruke, dakle značenja propovijedi koje je oblikovao propovjednik u osami svoje radne sobe. Slušatelji sada interpretiraju primljene informacije i podatke, a da bi taj proces tumačenja bio potpun, oni oblikuju povratnu informaciju. To vrijedi čak i u slučaju najstatičnije i najmonotonije monološke propovijedi - komunikacija se nastavlja i širi tako što slušatelji preuzimaju ulogu pošiljatelja i u suprotnom smjeru odašilju revidiranu ili potpuno novu poruku. Točno je, priznaje Kraft, da se taj »obrat smjera kretanja poruka « ostvaruje ponajprije neverbalnim sredstvima, ali on ipak ispunjava sve svrhe komunikacije. ${ }^{39}$ Taj obrat potom stvara očekivanje ponovnoga obrata i to zato što su povratne informacije izraz slušateljeve čežnje da ga se sasluša i da mu se odgovori. Kraft ovdje upozorava da bi pošiljatelj feedbacka mogao doživjeti frustraciju ako se njegove povratne informacije ignoriraju, a potom ne samo prestati slati povratne informacije nego i prestati mariti za sadržaj izvorne poruke. ${ }^{40}$ Implikacije toga uvida za propovjednika i njegovo slušateljstvo više su nego očite.

\footnotetext{
${ }^{37}$ Kraft tu spoznaju naziva $\gg$ najopasniji uvid suvremene teorije komunikacije za kršćanske komunikatore «. Usp. C. H. KRAFT, Communication Theory for Christian Witness, 92.

${ }^{38}$ D. J. RANDOLPH, The Renewal of Preaching, 23.

${ }^{39}$ C. H. KRAFT, Culture, Communication and Christianity, Pasadena, 2001., 217.

${ }^{40}$ C. H. KRAFT, Communication Theory for Christian Witness, 77.
} 
Tomu treba dodati i izrazito osobnu prirodu značenja ${ }^{41}$ - novije komunikacijske teorije uče nas da ne postoji propovijed s univerzalnim i općim značenjem koje bi svi slušatelji jednoznačno prihvatili. Mnogostrukost značenja zapravo odražava mnogostrukost iskustava. Propovijedanje evocira značenja u ljudima i priziva ih iz njihovih iskustava. ${ }^{42}$ Postoji, naravno, opasnost da se ljudsko iskustvo učini isključivim područjem propovjednoga govora o Bogu i da se iskustvena dimenzija doživljaja slušanja propovijedi nepotrebno i štetno razdvoji od kognitivne i voljne dimenzije. ${ }^{43}$ Međutim iz komunikacijske perspektive to isticanje iskustva interpretatora logična je posljedica pomaka pozornosti prema ulozi primatelja. U proteklim desetljećima postupno je prikupljen solidan fond empirijskih dokaza da vjernici uglavnom pozitivno doživljaju pokušaje svojih propovjednika da propovijedi dovedu na poznat teren njihovih životnih iskustava. ${ }^{44}$

Cilj tradicionalnoga propovijedanja bio je uvjerljivom prezentacijom postići željeni učinak kod slušatelja: bilo da je riječ o usvajanju novih znanja i spoznaja o Bogu, o pružanju duhovnoga vodstva, o poticaju na pokajanje ili o duhovnoj formaciji vjernika. Bez obzira na željenu svrhu njezino ostvarenje u najvećoj mjeri ovisilo je o propovjednikovoj sposobnosti uvjeravanja. Homiletičari i danas prepoznaju raznovrsne ciljeve kojima se propovjednici rukovode $u$ tjednim pripremama svojih propovijedi ${ }^{45}$, ali njihovo postignuće danas bi moglo mnogo više ovisiti o aktivnijem angažmanu vjernika slušatelja. Poticanje takvoga angažmana oslanja se na prepoznavanje činjenice da slušatelji već ionako sudjeluju u procesu stvaranja značenja, pa im tako umjesto gotovih odgovora treba prethodno ponuditi pozorno oblikovana pitanja koja će ih potaknuti da se, odatle gdje ih je propovijed zatekla, pridruže propovjedniku u potrazi za odgovorima koje nudi susret $s$ Riječju Božjom. Djelotvorna homiletička komunikacija ne će slušatelje izvještavati o već prožvakanim i očekivanim rezultatima tuđih istraživanja, već će ih pozvati na pu-

\footnotetext{
${ }^{41}$ Za sažetu raspravu o problemu značenja unutar postojećih teorija komunikacije usp. S. W. LITTLEJOHN, Theories of Human Communication, 95-112.

${ }^{42}$ Radikalni zagovaratelji takvoga razumijevanja idu toliko daleko da kažu: »Ako se evanđelje ne može prizvati iz iskustva, nije ga moguće niti propovijedati.«, usp. F. G. IMMINK, Homiletics: The current debate, u: International Journal of Practical Theology 8(2004.)1, 89-121., ovdje 110.

${ }^{43}$ Za konciznu analizu te opasnosti usp. isto, 110-120.

${ }^{44}$ Za noviji doprinos na tom polju nastao istraživanjem u hrvatskim okvirima usp. E. ŠEBA, Sermon listening among the Croatian Baptists: A New Approach Based on Congregational Studies and Rhetoric, Chester, 2019., neobjavljena disertacija.
}

${ }^{45}$ Primjera radi usp. J. CHILDERS (ur.), Purposes of Preaching, St. Louis, 2004. 
tovanje na kojem i samostalno mogu doći do uzbudljivih otkrića koja će hraniti, poticati i preispitivati njihov vjernički život. ${ }^{46}$

Sve dosad rečeno o slušateljima zapravo nas dovodi do naizgled očite, a ipak znakovite tvrdnje: Propovijedanje ovisi o slušanju! Ne samo da vjernici očito slušaju propovjednika nego i propovjednik treba osluškivati reakcije vjernika za vrijeme propovijedi (ali i u širem smislu slušati kako vjernici žive i kakva su njihova iskustva Boga, vjere i života). Drugim riječima, slušanje je preduvjet svakoga smislenoga dijaloga u okviru propovijedanja. Upravo iz toga razloga slušanje treba prestati uzimati zdravo za gotovo, a početi mu pristupati kao odlučujućem čimbeniku životvornoga propovijedanja u bilo kojoj zajednici. To naravno zahtijeva promišljen angažman, ulaganje konkretnoga napora i svjesnu odluku i propovjednika i zajednice da pretvore propovijedanje u proces kojim se ostvaruje autentična komunikacija izrasla iz udruženoga napora da se sada i ovdje razumije što Bog poručuje čovjeku.

\section{Konverzacija kao nova paradigma propovijedanja}

Već i ovako letimičan pregled najznačajnijih tendencija u suvremenom propovijedanju koje su (barem djelomice) izazvane ili unaprjeđene spoznajama komunikacijskih teorija kao što su interakcijska i transakcijska otkriva nam da one mogu rezultirati dubokim promjenama i kompleksnijim poimanjem homiletičke komunikacije. S obzirom na dalekosežnost toga usložnjavanja i promjena, opravdano je razmišljati o postavljanju nove paradigme koja bi omogućila otkrivanje nepoznatih i razjašnjenje postojećih spoznaja o prirodi propovijedanja. Premda su u posljednjih nekoliko desetljeća razni autori nudili različite prijedloge ${ }^{47}$, ja ću se ovdje ograničiti samo na paradigmu konverzacije kao potencijalno najprimjerenije sinteze mogućih smjerova u propovjednoj praksi koji su se razvili na zasadama teorija ljudske komunikacije.

Različiti suvremeni homiletičari dali su svoje doprinose na temelju kojih bismo konverzaciju mogli početi sagledavati kao novu paradigmu. ${ }^{48}$ Unutar nje možemo svr-

${ }^{46}$ Ovdje obvezno valja spomenuti Freda B. Craddocka, jednoga od začetnika Nove homiletike, pokreta koji je u najvećoj mjeri sintetizirao spoznaje različitih disciplina i pretočio ih u svježe razumijevanje propovijedanja, pri čemu je posebno važno inzistiranje na induktivnom tijeku propovijedi koji se zasniva na slušateljevu postupnom dolaženju do zaključaka, pri čemu njegovo iskustvo igra presudnu ulogu. Usp. F. B. CRADDOCK, As One without Authority, Nashville, 1979.

${ }^{47}$ Neki od njih jesu »događaj « (D. J. RANDOLPH, The Renewal of Preaching) $\mathrm{i} \gg$ iskustvo « (F. B. CRADDOCK, As One without Authority; E. L. LOWRY, The Homiletical Plot: The Sermon as Narrative Art Form, Louisville, 1980.)

${ }^{48}$ Usp. J. HOLSTON, Dialogue Preaching, u: Restoration Quarterly 24(1981.), 89-97. Donosi sustavan prikaz glavnih modela. 
stati više teorijskih razrada i konkretnih, praktičnih pristupa. John S. McClure tako razvija svoje »kolaborativno propovijedanje $\ll \mathrm{i} \gg$ propovjedaonicu za okruglim stolom $\ll,{ }^{49}$ Ronald J. Allen i Lucy Rose zagovaraju $\gg$ konverzacijsku propovijed $\ll{ }^{50}$, a O. W. Allen predstavlja svoju $\gg$ konverzacijsku homiletiku $\ll^{51}$. Izdvojit ću nekoliko njihovih zajedničkih točaka kako bih ilustrirao prednosti te paradigme. Najprije, konverzacija znači da se sudionici izmjenjuju u ulogama pošiljatelja i primatelja, ali da svi zajednički rade na postizanju međusobnoga razumijevanja. Osim toga slušanje ima za cilj razumjeti onu drugu stranu i tako postupno doći do suglasja. Također konverzacija traži od sugovornika da zadrže stav otvorenosti - moguće je biti u krivu, pa i promijeniti mišljenje. Konačno, konverzacija se vodi jer se njezini sudionici međusobno istinski uvažavaju. Konverzacija uvažava stvarnost u kojoj smo već od ranoga djetinjstva izloženi raznim recipročnim procesima pa time ne samo da redefinira ulogu propovjednika već i cijelu propovijed pretvara u interakciju.

Ovdje se, dakako, postavlja pitanje kako je moguće propovijed kao monološki oblik komunikacije transformirati u nešto interaktivno ili kako je obogatiti nekim značajkama konverzacije. Ostavimo li po strani organizacijske i tehničke pojedinosti, postoje različiti načini uključivanja konverzacije u homiletičku praksu, a okvirno ih možemo razvrstati prema vremenu kada se konverzacija primarno odvija: prije, tijekom ili nakon propovijedi. ${ }^{52}$ Pokušaji uključivanja elemenata spontane konverzacije u propovijed i dijaloga zasnovanoga na reakcijama slušatelja na propovijed pokazali su se uglavnom neuspjelima izvan konteksta vrlo malih zajednica ili okruženja malih skupina za proučavanje Biblije. ${ }^{53}$ Upravo to je i nagnalo Reuela Howea da još 1967. godine provede jedno od prvih istraživanja o propovijedanju te da savjetuje uvođenje »dijaloškog načela «. Njegovom primjenom propovijed ostaje monolog, ali poduprt intenzivnim konverzacijama unutar eklezijalnoga konteksta, uslijed kojih propovjednik postaje sve senzibiliziraniji za iskustva, percepcije i kontekste svojih slušatelja, pa sukladno tomu i oblikuje svoje propovijedanje. Tako se i nastojanja da se konverzacija povede prije propovijedi temelje na raznim načinima da se vjernike uključi u proces proučavanja biblijskih čitanja i pripreme propovijedi, čime surađuju s propovjednicima u oblikovanju propovijedi koje onda reflektiraju

\footnotetext{
${ }^{49}$ J. S. McCLURE, Other-Wise Preaching: A Postmodern Ethic for Homiletics, St. Louis, 2001.; The Roundtable Pulpit: Where Leadership and Preaching Meet, Nashville, 1995.

${ }^{50}$ R. J. ALLEN, Interpreting the Gospel: An Introduction to Preaching, St. Louis, 1998.

${ }^{51}$ O. W. ALLEN, The Homiletic of All Believers: A Conversational Approach to Proclamation and Preaching.

${ }^{52}$ Kritički pregled tih pristupa može se pronaći u: isto, 6-15.

${ }^{53} \mathrm{U}$ novije vrijeme dijaloški oblik propovijedi uglavnom postoji u bogoslužju tzv. Emerging Church, a o tom fenomenu usp. npr.: E. GIBBS, R. K. BOLGER, Emerging Churches: Creating Christian Community in Postmodern Cultures, Grand Rapids, 2005.
} 
ili sadržaj susreta zajednice s porukom evanđelja ili dinamiku razgovora među vjernicima koji su se vodili tijekom pripreme..$^{54}$ Ipak, većina homiletičara motiviranih da službu propovijedanja promišljaju kroz prizmu konverzacije zalaže se za pokretanje i održavanje konverzacijskih procesa koji ne počinju samo propovjednikovim osluškivanjem svojih vjernika i prije nego što stane za propovjedaonicu nego i onih koji se u zajednici zbivaju izvan domene propovijedanja, a oblikuju njezin identitet i vjeru. Tako primjerice Rose predlaže pristup prema kojemu propovjednik najprije staje na stranu zajednice, nasuprot biblijskomu tekstu, a potom predstavlja provizorno tumačenje toga teksta. Zajednica tada otpočinje niz konverzacija tijekom kojih može dorađivati, preinačivati ili proturječiti tom ponuđenom značenju. ${ }^{55}$ Ronald J. Allen smatra da se konverzacija mora zasnivati na »uzajamnoj kritičkoj korelaciji « između drevne kršćanske tradicije i suvremene situacije obilježene društvenim, kulturnim i teološkim odrednicama. ${ }^{56}$ Tako se razgovor ne ograničava na komunikaciju između propovjednika i slušatelja - naprotiv, popis konverzacijskih partnera širi se na Bibliju, kršćansku tradiciju, povijest kršćanstva, suvremene teologe, zajednicu, šire društvo, propovjednikovo životno iskustvo i Boga. O. Wesley Allen ističe da konverzacijska homiletika počinje $\gg . .$. priznanjem da je naviještanje evanđelja odgovornost crkve i da se ono odvija putem matrice teoloških, religijskih, političkih i osobnih konverzacija, a ne samo obveza propovjednika koji usamljen stoji za propovjedaonicom $\ll .{ }^{57}$ Tako shvaćena, konverzacija zapravo predstavlja stanje uma i dinamiku koja nema konačnu odredišnu točku, a traži nešto što $O$. W. Allen naziva recipročnim slušanjem i definira kao »( ... ) slušanje obilježeno rizikom, odsutnošću predrasuda, te voljom i željom za obraćenjem $\ll_{.}^{58}$

\section{Zaključak}

U konačnici, dopuštanje homiletici da se obogati spoznajama komunikacijskih teorija zacijelo može otvoriti neke nove obzore i stvoriti prostor za nove vjetrove $u$ propovjedničkoj praksi. Paradigma konverzacije neminovno može pripomoći da se propovijedanje počne više promišljati i ostvarivati kao sastavni dio liturgije i crkvenoga života koji aktivnije promiče komunikaciju i bolje razumijevanje - i to ne

\footnotetext{
${ }^{54}$ Za pristupe toga tipa usp. J. S. McCLURE, The Roundtable Pulpit: Where Leadership and Preaching Meet; B. BARR, Parish Back Talk, Nashville, 1964.; D. RITSCHL, A Theology of Proclamation, Louisville, 1960.

${ }^{55}$ L. A. ROSE, Sharing the Word: Preaching in the Roundtable Church, Louisville, 1997., 89-118.

${ }^{56}$ R. J. ALLEN, Preaching as Mutual Critical Correlation through Conversation, u: J. CHILDERS (ur.), Purposes of Preaching, 1-22.

${ }^{57}$ O. W. ALLEN, The Homiletic of All Believers: A Conversational Approach to Proclamation and Preaching, 15.

${ }^{58}$ Isto, 41.
} 
samo na relaciji svećenik/propovjednik - vjernici/slušatelji. Hoće li se to uistinu i dogoditi u svakodnevnoj praksi različitih crkvenih zajednica na našim prostorima, ovisit će u znatnoj mjeri o brojnim čimbenicima od kojih (ne)sklonost k preispitivanju postojećih modela propovijedanja svakako pripada značajnijima. U tom pogledu smatram da bi se upuštanje u svojevrstan rizik moglo pokazati plodonosnim za zajednicu, tim više što, kako to kaže Cox: $\gg A$ priori pretpostavljati da je Bog zarobljen u teološkom sustavu pošiljatelja i da više nije slobodan progovoriti izvan tog sustava znači onemogućavati bilo kakav dijalog i ušutkavati Boga koji odbija biti zarobljenikom bilo kojeg čovjeka ili sustava. $\ll{ }^{59}$ Međutim svakako valja zadržati na umu i u srcu da ni jedna propovijed, pa ni propovijed oslonjena o koncept konverzacije, još uvijek ne može niti će ikada moći do kraja iskazati otajstvo koje naviješta. To pak ne treba biti obeshrabrenje, nego poticaj za divljenje veličanstvenosti toga otajstva. Homiletičar Eugene Lowry prikladno je to sažeo ovim riječima: $\gg(. .$.$) u određenom smislu propovijed nije važna. Važno je ono što propovjednik$ ne može reći jer neizrecivo ostaje neizrecivo, a sve što se može učiniti jest prema tom neizrecivome gestikulirati najljepšim dostupnim riječima. ${ }^{60}$

${ }^{59}$ J. W. COX, Preaching, 56.

${ }^{60}$ E. L. LOWRY, The Homiletical Plot: The Sermon as Narrative Art Form, 38. 


\title{
SOME RECENT HUMAN COMMUNICATION THEORIES AND THEIR IMPLICATIONS FOR HOMILETICS
}

\author{
Enoh $\check{\text { SEBA* }}$
}

Summary: Viewed from the perspective of communication processes, it may be concluded that traditional preaching mostly follows the linear model of interpersonal communication. However, this relationship entails limitations that prevent preaching from reaching its full communicational potential. This paper evaluates some recent communication models (interactional and transactional) in order to, first, highlight their particular advantages over the linear model (i.e. the reciprocity of communication and the presence of feedback, the role of nonverbal communication, the relational dimension of communication, the process of creating meaning...), and also to suggest some concrete ways for their application in homiletical practice which would contribute to a more comprehensive understanding of preaching and its improvement. Furthermore, the aim is to underline how the application of these insights can redefine the roles of key participants in homiletical communication - the preacher, the believers, and the message. The scope of these changes points to the possibility to start considering preaching within the framework of a different, new paradigm - the paradigm of conversation. Such a change in the frame of reference makes it easier to reflect on preaching which, while preserving its monologue form, in fact promotes dialogue, mutuality, and a higher level of understanding within the community of faith.

Keywords: communication theories, homiletics, preaching, conversation, dialogue.

\footnotetext{
* Enoh Šeba, Ph.D., University of Zagreb, Centre for Protestant Theology Matthias Flacius Illyricus, Ivana Lučića 1a, 10000 Zagreb, Croatia, enoh.seba@tfmvi.hr
} 